\title{
Geo-spatial technique-based approach on drainage morphometric analysis at Kalrayan Hills, Tamil Nadu, India
}

\author{
R. Sakthivel ${ }^{1} \cdot$ N. Jawahar $\operatorname{Raj}^{2} \cdot$ V. Sivasankar ${ }^{3,4} \cdot$ P. Akhila $^{1} \cdot$ Kiyoshi Omine $^{3}$
}

Received: 6 January 2017 / Accepted: 18 January 2019 / Published online: 30 January 2019

(c) The Author(s) 2019

\begin{abstract}
Drainages are pulses which in turn help us to understand the ongoing process in the hill ecosystem. The Kalrayan hill is known for its dissected terrain condition, rich biological diversity and depletion of natural resources. Therefore, a study on quantitative geomorphometry was carried out in the Kalrayan Hills, Eastern Ghats, Tamil Nadu, using Indian remote sensing 1D LISSIII satellite data. The study area was divided into 36 watersheds and total area is $1158.4 \mathrm{~km}^{2}$. It covers the upper part of Vellar basin. The linear, aerial and relief aspects and different morphometric parameters such as stream length, bifurcation ratio, drainage density, stream frequency, drainage texture, relief ratio, basin shape, form factor, circularity ratio, elongation ratio and length of overland flow were computed using standard methods, formulae and geo-spatial technologies. Based on the present drainage morphometric study, it is inferred that the watersheds $3,4,6,9,11,12,15,17,18,19,20,22,24,27$, $32,33,34$ and 36 are active with reference to geological processes, mean denudational rate, peak discharge, mean annual run off, dominant watershed process and sediment yield per unit area. Multi-criteria analysis is performed to determine the drainage architecture and hydrogeological processes occurring in the present hill area.
\end{abstract}

Keywords Basin hydrology $\cdot$ Morphometric parameters $\cdot$ Water resource management $\cdot$ Kalrayan hills $\cdot$ Multi-criteria analysis

\section{Introduction}

The study on basin hydrology is essential for proper management of water resources, and flood hazard in a basin depends upon the hydrological response of the upstream basin area. In geomorphology, morphometry is dedicated to the quantification of morphology. Shape indices used in drainage basin morphometry relate to the quantification of basin shape. Morphometric characteristics of drainage basins provide a means for describing the hydrological behavior of a basin.

R. Sakthivel

drsvel@gmail.com

1 Department of Geology, School of Geosciences, Bharathidasan University, Tiruchirappalli 620 024, India

2 Post Graduate and Research Department of Geology, National College, Tiruchirappalli 620 001, India

3 Department of Civil Engineering, School of Engineering, Nagasaki University, Nagasaki-Daigaku, 1-14 Bunkyo-machi, Nagasaki 852 8521, Japan

4 Post Graduate and Research Department of Chemistry, Pachaiyappa's College, Chennai 600 030, Tamil Nadu, India
Drainage basin is a geohydrological unit area drained to a common point considering it as an ideal unit for analysis and management of natural resources and environmental planning in any ridge to valley treatment. The knowledge of basin hydrology is imperative for proper management of natural resources in general and water resources in particular. Hydrological parameters help in quantification of water available, amount utilized and the additional exploitable resources available for producing green biomass in the area. The characteristics of basin morphometry have been used to predict or describe geomorphic processes such as prediction of flood peaks, assessment of sediment yields and estimation of erosion rates (Patton and Baker 1976; Baumgardner 1967; Gardiner 1990; Patton 1988). Drainage basins are the fundamental units of the fluvial landscape, and a great amount of research has focused on their geometric characteristics (Abrahams 1984). The study of drainage characteristics through morphometric analysis of different watersheds in a region gives much information regarding the denudational history, sub-surface material, geological structure, soil type and vegetation status of that region, which play a crucial role in formulating a plan for watershed management. It implies 
the proper use of land and water resources of a watershed for optimum production with minimum hazard to natural resources (Jawaharraj et al. 1998; Biswas et al. 1999).

Morphometry is the measurement and mathematical analysis of the configuration of the Earth's surface, shape and dimensions of its landforms (Clarke 1966). Morphometric studies involve evaluations of streams through the measurement of various stream properties. Evaluation of morphometric parameters necessitates the analysis of various drainage parameters (Verstappen 1983; Kumar et al. 2000). The descriptive approach involves the study of the characteristics of the forms and patterns of the streams while the genetic approach involves investigation of the evolution of streams of a region in relation to tectonics, lithology and structure (Singh 1998). Chaudhary and Sharma (1998) performed erosion hazard assessment and prioritization based on morphometric parameters like relief ratio, drainage density, drainage texture and bifurcation ratio. The drainage basin analysis is important in any hydrological investigation like assessment of groundwater potential, groundwater management, pedology and environmental assessment. Hydrologists and geomorphologists have recognized that certain relations are most important between runoff characteristics, geographic and geomorphic characteristics of drainage basin systems (Sreedevi et al. 2009). Morphometric analysis requires measurement of linear features, areal aspects, gradient of channel network and contributing ground slopes of the drainage basin (Nautiyal 1994); Nag and Chakraborty 2003). Moussa (2003) has stated that one of the important problems in hydrology is the quantitative description of river system, structure and the identification of relationships between geomorphological properties and hydrological response. The quantitative drainage character assessment is an important input to understand the ongoing geological processes, rate of denudation, sediment yield, peak discharge and mean annual runoff. Many research works have been reported on morphometric analysis using remote sensing and G1S techniques. Shrimali et al. (2001) presented a case study of the Sukhana lake $\left(42 \mathrm{~km}^{2}\right)$ catchment in the Shiwalik hills for the delineation and prioritization of soil erosion areas by using remote sensing and GIS techniques. Srinivasa et al. (2004) adopted the remote sensing and GIS techniques in morphometric analysis of sub-watersheds of Pawagada area, Tumkur district, Karnataka. Chopra et al. (2005) carried out morphometric analysis of Bhagra-Phungotri and Hara Maja subwatersheds of Gurdaspur district, Punjab. Rodriguez-Iturbe and Valdés (1979) proposed the geomorphological instantaneous unit hydrograph (GIUH) theory where an IUH is fitted through three points (namely $t_{p}, q_{p}$ and $t_{B}$ ) and suggested simple expressions for the $t_{p}$ and $q_{p}$ of the IUH obtained by regression of the peak as well as time to peak of IUH derived from the analytic solutions for a wide range of parameters with that of the geomorphologic characteristics and flow velocities. The GIUH model provided a scientific basis for the hydrograph fitting and yielded a smooth and single-valued shape corresponding to unit runoff volume. Nookaratnam et al. (2005) carried out study on check dam positioning by prioritization of micro-watersheds using the sediment yield index (SY1) model and morphometric analysis using remote sensing and GIS. Richard and Pike (2000), Bardossy and Schmidt (2002), Grohmann (2004), Marchi and Fontana (2005), Kouli et al. (2007), Esper (2008), Hlaing et al. (2008), Akar (2009), Ajibade et al. (2010) and Thomas et al. (2010) used remote sensing and GIS techniques for drainage morphometry analysis. Das and Pardeshi (2018) worked on the morphometric analysis of Vaitarna and Ulhas river basins in Maharashtra. Radwan et al. 2017 and Malik and Shukla (2018) reported on the analysis, respectively, in the Wadi Baish dam catchment area and Kandaihimmat watershed in Madhya Pradesh using GIS-based approach. Kumar et al. 2018 explored this analysis using open-access earth observation datasets in the drought-affected part of Bundelkhand, India. Mahmoud and Alazba (2015) and Kumar et al. 2014 respectively demonstrated the morphometric and geophysical analyses of major rainwater harvesting basins in Saudi Arabia and six sub-watersheds in the central zone of Narmada river in India. In the present contribution, a quantitative geo-morphometric study was attempted to explore the relationship between drainage signatures and management of natural resources in general and water resources in particular in the Kalrayan Hills located in the Eastern Ghats of Tamil Nadu, South India. The objectives of the present research were motivated in the direction of exploring the groundwater potential locations on the hilly terrain, based on the knowledge of surface and sub-surface flow patterns of water. Through the assessment of the drainage network and relief parameters together with climatic conditions, tectonics and lithology, the hydro-geomorphic characteristics and the stage of basin development on the Kalrayan hills, Tamil Nadu, have been detailed in this paper.

\section{Study area}

The study area, Kalrayan hills, chosen for the present study (Fig. 1) is Upper part of Vellar basin of Tamil Nadu. The Kalrayan hills which is a major hill range of Eastern Ghats of Tamil Nadu, South India, bounded by Attur taluk in the south, Kallakurichi taluk in the east and Harur taluk in the west. The study area lies between $11^{\circ} 36^{\prime}-12^{\circ} 02^{\prime} \mathrm{N}$ and $78^{\circ} 28^{\prime}-78^{\circ} 59^{\prime}$, and it covers an area of $1158.4 \mathrm{~km}^{2}$. The annual rainfall ranges from 700 to $1569 \mathrm{~mm}$ (Sakthivel et al. 2007). The temperature varies from a minimum of $25^{\circ} \mathrm{C}$ to a maximum of $40{ }^{\circ} \mathrm{C}$ and the altitude varies from 126 to $1298 \mathrm{~m}$ (Sakthivel et al. 2010, 2011). Gomukhi and Manimuktha rivers originate in the study area (Fig. 2). Numerous 


\section{KALRAYAN HILLS AND ITS ENVIRONS LOCATION MAP}
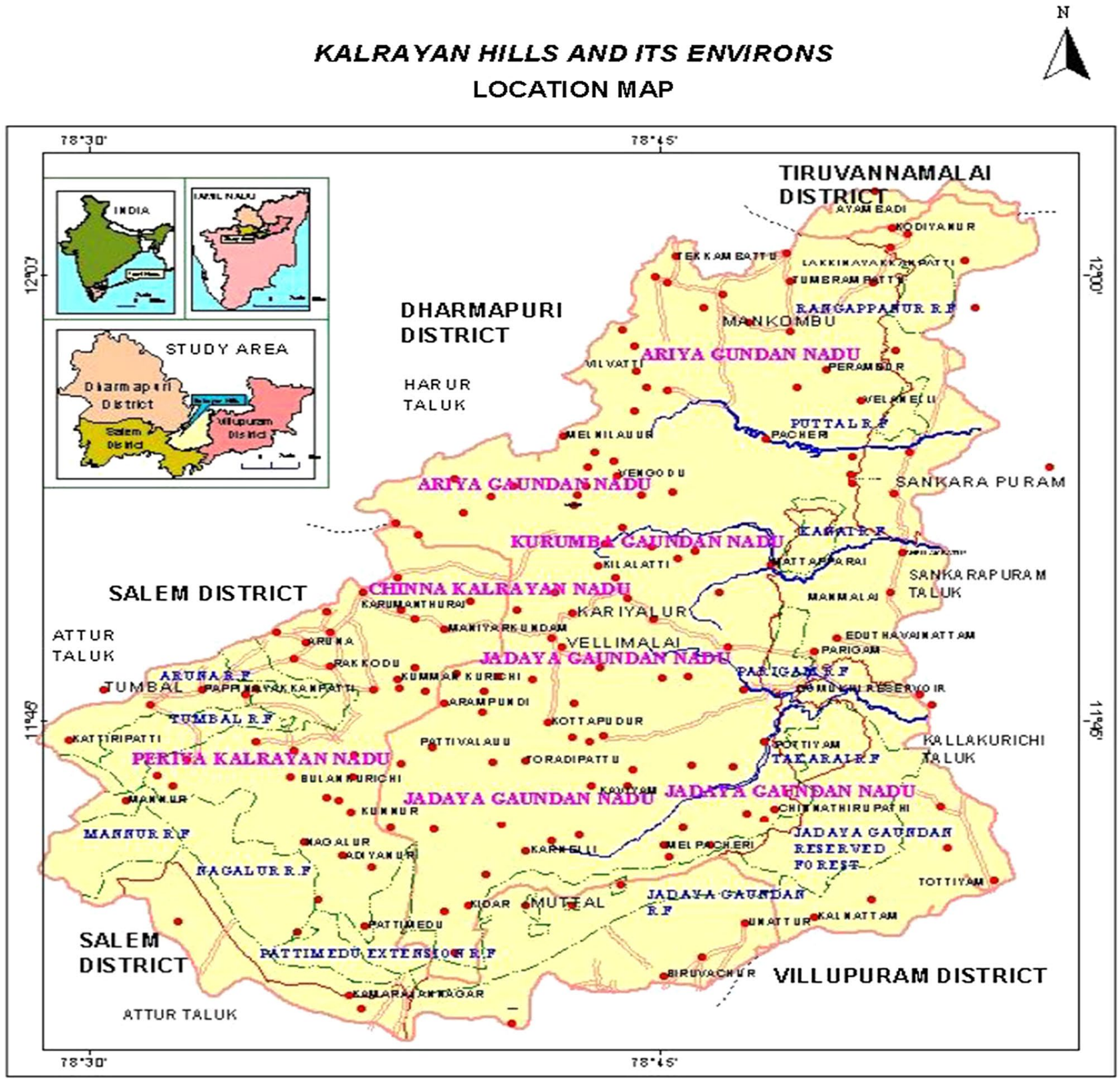

\section{LEGEN D}

$\checkmark$ Study Area Boundary

$\therefore \because$ Disrtict Boundary

Adminstrative Block Boundany

7 Reserwed Forest Boundany

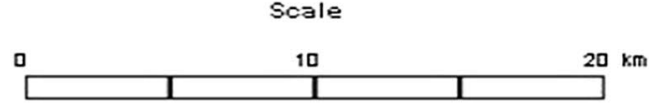

1 Roads

- Settlement

$\checkmark$ Rivers

Fig. 1 Location map of the study area

lineaments and their points of intersection have been identified, and most of them show NE-SW trending direction (Sakthivel et al. 2003). A prominent shear zone trending in $\mathrm{N}-\mathrm{S}$ direction cut across the entire hills (Sakthivel et al. 2010). The study area experiences minor tremors recently (Pirasteh et al. 2011). 
Fig. 2 Watershed map of the study area

KALRAYAN HILLS AND ENVIRONS

WATERSHEDS

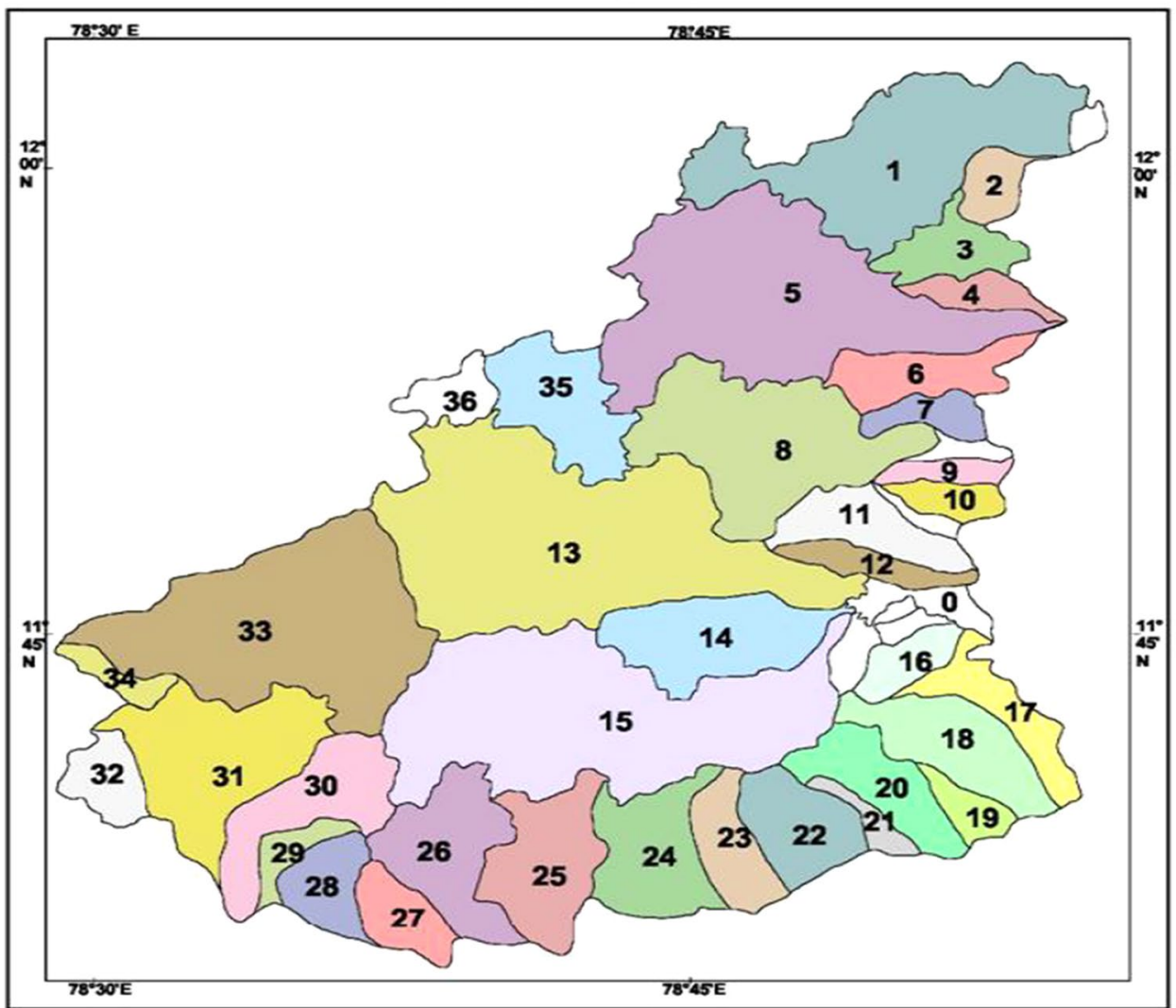

\section{LEGEND}

Watersheds

Other area

\section{Methodology}

Morphometric analysis of a drainage system requires a delineation of all existing streams and reaches. There are several methods followed for the delineation of drainage system, but in most of the studies manual and automated system is followed (Saud 2009). In the present study, also both conventional and contemporary techniques were applied. The Survey of India (SOI) toposheets (Year of Survey: 1971), IRS 1D LISS III Geocoded satellite data (Year of acquisition: 2001) on 1: 50,000 scale were made use of. The drainages have been delineated using merged satellite data of Geocoded FCC of bands-2 34 on 1:50,000 scale and SOl toposheets have been used as a reference. Necessary field check has been carried out. Softwares like ERDAS IMAGINE (V.8.5), ArcInfo (V 8.1.2) and ArcView (V 3.2a) have been used for dereferencing, digitization and computational purpose and also for output generation, respectively. The statistical interpretations are made with the help of factor analysis, hierarchial cluster analysis and box plots using the SPSS software (version 21) package.

\section{Results and discussion}

\section{Linear aspects}

Linear aspects of the watersheds are related to the channel patterns of drainage network wherein the topological characteristics of the stream segments in terms of open links of the stream network system were analyzed. The parameters such as number of streams, streams length, bifurcation ratio and length ratio were taken into account for the present study and are calculated using the corresponding formula as shown in Table 1. The parametric results are tabulated in Table 2 . 
Table 1 Formulae adopted for computation of morphometric parameters

\begin{tabular}{|c|c|c|c|}
\hline Sl. no. & Morphometric parameters & Formula & References \\
\hline 1 & Stream order & Hierarchial rank & Strahler (1964) \\
\hline 2 & Stream length $(\mathrm{Lu})$ & Length of the stream & Horton (1945) \\
\hline 3 & Mean stream length (Lsm) & $\begin{array}{l}\mathrm{Lsm}=\mathrm{Lu} / \mathrm{Nu} \\
\mathrm{Lu}=\text { Total stream length of order } \\
\mathrm{Nu}=\text { Total no. of stream segments of order }\end{array}$ & Strahler (1964) \\
\hline 4 & Stream length ratio (RL) & $\begin{array}{l}\mathrm{RL}=\mathrm{Lu} / \mathrm{Lu}-1 \\
\mathrm{Lu}=\mathrm{The} \text { total stream length of the order } \\
\mathrm{Lu}-1=\text { The total stream length of its next lower order }\end{array}$ & Horton (1945) \\
\hline 5 & Bifurcation ratio $(\mathrm{Rb})$ & $\begin{array}{l}\mathrm{Rb}=\mathrm{Nu} / \mathrm{Nu}+1 \\
\mathrm{Nu}=\mathrm{Total} \text { no. of stream segments of order } \\
\mathrm{Nu}+1=\text { Number of segments of the next higher order }\end{array}$ & Schumn (1954) \\
\hline 6 & Mean bifurcation ratio ( $\mathrm{Rbm})$ & $\mathrm{Rbm}=$ Average of bifurcation ratios of all orders & Strahler (1957) \\
\hline 7 & Relief ratio (Rh) & $\begin{array}{l}\mathrm{Rh}=H / \mathrm{Lb} \\
H=\text { Relative relief of the basin }(\mathrm{km}) \\
\mathrm{Lb}=\text { Basin length }\end{array}$ & Schumn (1954) \\
\hline 8 & Drainage density (D) & $\begin{array}{l}D=\mathrm{Lu} / A \\
\mathrm{Lu}=\text { Total stream length of all orders } \\
A=\text { Area of the basin }\left(\mathrm{km}^{2}\right)\end{array}$ & Horton (1932) \\
\hline 9 & Stream frequency $(\mathrm{Fs})$ & $\begin{array}{l}\mathrm{Fs}=\mathrm{Nu} / A \\
\mathrm{Nu}=\mathrm{Total} \text { no. of streams of all orders } \\
A=\text { Area of basin }\left(\mathrm{km}^{2}\right)\end{array}$ & Horton (1932) \\
\hline 10 & Drainage texture (Rt) & $\begin{array}{l}\mathrm{Rt}=\mathrm{Nu} / P \\
\mathrm{Nu}=\mathrm{Total} \text { no. of streams of all orders } \\
P=\text { Perimeter }(\mathrm{km})\end{array}$ & Horton (1945) \\
\hline 11 & Form factor (Rf) & $\begin{array}{l}\mathrm{Rf}=A / \mathrm{Lb}^{2} \\
A=\text { Area of the basin }\left(\mathrm{km}^{2}\right) \\
\mathrm{Lb}^{2}=\text { Square of basin length }\end{array}$ & Horton (1932) \\
\hline 12 & Circulatory ratio $(\mathrm{Rc})$ & $\begin{array}{l}\mathrm{Rc}=4 * \mathrm{Pi} * A / P^{2} \\
\mathrm{Pi}=\text { 'Pi' value i.e., } 3.14 \\
A=\text { Area of the basin }\left(\mathrm{km}^{2}\right) \\
P^{2}=\text { Square of the perimeter }(\mathrm{km})\end{array}$ & Miller (1957) \\
\hline 13 & Elongation ratio $(\mathrm{Re})$ & $\begin{array}{l}\operatorname{Re}=2 \sqrt{ }(A / \mathrm{Pi}) / \mathrm{Lb} \\
A=\text { Area of the basin }\left(\mathrm{km}^{2}\right) \\
\mathrm{Pi}=3.14 \\
\mathrm{Lb}=\text { Basin length }\end{array}$ & Schumn (1954) \\
\hline 14 & Length of overland flow $\left(L_{o}\right)$ & $\begin{array}{l}\mathrm{Lg}=1 / D^{*} 2 \\
D=\text { Drainage density }\end{array}$ & Horton (1945) \\
\hline
\end{tabular}

\section{Stream order and stream numbers}

Stream order refers to the determination of the hierarchical position of the streams within a drainage watershed. The streams of the study area have been ordered according to the stream ordering method of Strahler (1957). The highest stream orders for the various watershed of the study area are given in Table 2. From the table, it is evident that among the watersheds, the highest stream order was noticed for the watersheds $1,5,8,13,14,18,24,26,31,33$ and 35 all of which are found to be of fifth order. On the other hand, watershed 9 and 19 were found to be of the least order both of which are found to be of second order.

Among the various watersheds in the study area, the percentage of first-order stream was found to be maximum for watershed 34 that constitute of 90 per cent of its stream as I order streams. Watersheds 15, 19, 21, 29, 31, 34 and 36 also had relatively higher percentage of I order streams ( $>80 \%)$. The percentage was found to be the least for watershed 2 which had only about 66.6 per cent of the first-order streams. Watersheds 2, 22 and 32 had relatively lesser percentages of I order streams $(<70 \%)$. The percentages of the first-order streams in rest of the other watershed were found to be moderate (70-80\%). It was observed that the numbers of stream segments decreased with the increase in the stream order for all the watersheds of the study area.

\section{Total stream length (Lu)}

The total stream length, which refers to the sum total of the stream length of all orders in a given watershed, has been estimated for the watershed of the study area (Table 2). The

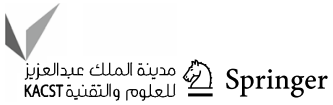


Table 2 Linear aspects of the watersheds in Kalrayan hills

\begin{tabular}{|c|c|c|c|c|c|c|}
\hline Basin no. & $\begin{array}{l}\text { Total stream } \\
\text { numbers }\end{array}$ & $\begin{array}{l}\text { Total stream } \\
\text { length }\end{array}$ & $\begin{array}{l}\text { Average bifur- } \\
\text { cation ratio }\end{array}$ & $\begin{array}{l}\text { Average } \\
\text { stream length }\end{array}$ & $\begin{array}{l}\text { Length } \\
\text { ratio (Rl) }\end{array}$ & $\% 1$ order stream \\
\hline 1 & 303 & 212 & 4.01 & 2.51 & 0.77 & 78.22 \\
\hline 2 & 33 & 26 & 2.71 & 0.82 & 0.95 & 66.67 \\
\hline 3 & 64 & 45 & 4.11 & 1.31 & 0.56 & 78.12 \\
\hline 4 & 28 & 21.5 & 4.75 & 1.81 & 0.46 & 75 \\
\hline 5 & 545 & 250.5 & 4.77 & 4.12 & 0.47 & 77.43 \\
\hline 6 & 70 & 34 & 3.8 & 1.67 & 0.62 & 75.71 \\
\hline 7 & 29 & 25.5 & 4.8 & 2.49 & 0.48 & 79.31 \\
\hline 8 & 401 & 156.2 & 4.29 & 2.45 & 0.51 & 77.8 \\
\hline 9 & 4 & 8 & 3 & 2 & 1 & 75 \\
\hline 10 & 11 & 14.5 & 3 & 1.79 & 0.69 & 72.73 \\
\hline 11 & 75 & 53.5 & 3.91 & 2.36 & 0.55 & 76 \\
\hline 12 & 50 & 35.5 & 3.62 & 1.87 & 0.99 & 78 \\
\hline 13 & 528 & 382.6 & 4.55 & 4.71 & 0.51 & 79.73 \\
\hline 14 & 166 & 74.5 & 3.65 & 1.75 & 0.67 & 78.31 \\
\hline 15 & 697 & 438 & 4.92 & 4.98 & 0.45 & 81.2 \\
\hline 16 & 47 & 40 & 3.49 & 1.32 & 1.25 & 76.59 \\
\hline 17 & 19 & 38 & 4 & 1.89 & 3.6 & 78.95 \\
\hline 18 & 90 & 83.5 & 3.04 & 1.98 & 0.79 & 75.55 \\
\hline 19 & 5 & 10.5 & 4 & 2.62 & 0.5 & 80 \\
\hline 20 & 85 & 61 & 4.13 & 2.16 & 0.84 & 77.65 \\
\hline 21 & 15 & 13 & 4 & 1.15 & 1.07 & 80 \\
\hline 22 & 83 & 66.5 & 3.96 & 1.85 & 0.53 & 71.08 \\
\hline 23 & 31 & 29.2 & 2.83 & 2.15 & 0.87 & 67.74 \\
\hline 24 & 105 & 79.75 & 3.04 & 1.25 & 3.77 & 72.38 \\
\hline 25 & 134 & 76 & 3.83 & 1.73 & 0.47 & 78.36 \\
\hline 26 & 182 & 119.5 & 3.68 & 1.97 & 0.63 & 77.47 \\
\hline 27 & 31 & 34 & 3.03 & 1.06 & 2.91 & 74.19 \\
\hline 28 & 37 & 35.5 & 3.91 & 1.74 & 0.5 & 78.38 \\
\hline 29 & 24 & 22 & 4.83 & 2.31 & 0.37 & 83.33 \\
\hline 30 & 114 & 85 & 4.53 & 2.87 & 0.44 & 78.95 \\
\hline 31 & 176 & 127 & 3.74 & 2.02 & 0.75 & 81.25 \\
\hline 32 & 113 & 71 & 4.6 & 1.25 & 0.68 & 71.68 \\
\hline 33 & 402 & 272 & 4.23 & 3.91 & 0.55 & 76.86 \\
\hline 34 & 30 & 19 & 7.7 & 1.59 & 0.45 & 90 \\
\hline 35 & 141 & 97 & 3.37 & 1.21 & 1.96 & 76.59 \\
\hline 36 & 38 & 29.5 & 5.7 & 1.77 & 0.43 & 84.21 \\
\hline
\end{tabular}

total stream length is higher $(>100 \mathrm{~km})$ for the watershed 1 , $5,8,13,15,26,31$ and 33 with the highest length being for watershed 15 which had a stream length of $438 \mathrm{~km}$. On the other hand, it was found to be lower $(<50 \mathrm{~km})$ for watershed 2, 3, 4, 6, 7, 9, 10, 12, 16, 17, 19, 21, 23, 27, 28, 29 and 34. Rest of the watershed has moderate stream length.

Morisawa (1962) has observed that the total stream length is directly related to mean annual runoff. Stream length ratio between successive streams orders varies due to differences in slope and topographic conditions and has an important relationship with the surface flow discharge and erosional stage of the basin (Sreedevi et al. 2005). From this observation, it is clear that the mean annual runoff is relatively higher in watershed $1,5,8,13,15,26,31$ and 33 whereas the mean annual runoff is relatively lower in watershed 2, 3, 4, 6, 7, 9, 10, 12, 16, 17, 19, 21, 23, 27, 28, 29 and 34 . For the other watersheds, the mean annual runoff is moderate.

\section{Bifurcation ratio $\left(R_{b}\right)$}

Bifurcation ratio, related to the branching pattern of the drainage network, is defined as the ratio of the number of streams of an order to the number of streams of the next 
higher order (Horton 1945). The bifurcation ratio values obtained for the watershed of the study area are shown in Table 2. Among the watersheds of the hills, the bifurcation ratio values are found to range from 2.71 (watershed 2) to 7.7 (watershed 34) and they found to be relatively higher $(>5)$ for watersheds 34 and 36 . Whereas, the bifurcation ratio values were found to be lower $(<3)$ for watersheds 2 and 3. According to Horton (1945) and Strahler (1968), the bifurcation ratio values range from 2 to 5 in a welldeveloped drainage network. Strahler (1964) and Nautiyal (1994) have found that higher bifurcation ratio values are characteristics of watersheds, which have suffered more structural disturbances and it is very much controlled by the watershed shape and shows very little variations ranging between 3 and 5 in homogenous bedrock. As per view expressed by Strahler (1964) and Nautiyal (1994), it is inferred that watersheds 34 and 36 have suffered more structural disturbances.

\section{Length ratio $(R \mathrm{I})$}

The proportion of increase in mean length in stream segments of two successive watersheds orders is defined as length ratio (Singh 1978). The length ratio values obtained for the watersheds of the study area range from 0.37 (watershed 29) to 3.77 (watershed 24). Higher length ratio values $(>1.5)$ were observed for watersheds $9,16,17,24,27$ and 35 . The lower length ratio values $(<0.5)$ were observed for $4,5,7,15,25,30,34$ and 36 . Length ratios are found to be moderate in other watersheds. According to Kumaraswamy and Sivagnanam (1988), the larger length ratio values indicate lower order sources for the next higher order streams, whereas the smaller values indicate the limited length of lower order streams to serve as hydrological sources. The watersheds 9, 16, 17, 24, 27 and 35 contain more lower order sources for the next higher order, whereas for watersheds 4 , $5,7,15,25,34$ and 36 the lower order sources are relatively less.

\section{Basin length $\left(L_{b}\right)$}

The watershed length is the longest length in the watersheds in one end being the mouth (Gregory and Walling 1973). Based on the above definition, the lengths of the watershed of the study area were calculated and are shown in Table 2. In this region, watershed length varies from $3.1 \mathrm{~km}$ (watershed 2) to $22.85 \mathrm{~km}$ (watershed 15). The watersheds $1,5,8$, $13,14,15$ and 33 have greater length $(>12 \mathrm{~km})$ whereas for $3,7,9,10,16,19,27,28,29,32,34$ and 36 with the length $(<6 \mathrm{~km})$. In the other watersheds the length varies from $(6$ km-12 km).

\section{Aerial aspects}

To understand the aerial aspects, the parameters that have been considered for the present study are watershed area, drainage density, stream frequency, circularity ratio, perimeter and length of overland flow. The procedures followed and the results obtained (Table 3 ) have been discussed in this section.

\section{Basin area $(A)$}

The watershed area was delineated on the basis of water divides, and the aerial extents were measured with the help of digital planimeter. The area computed for the watersheds is shown in Table 3. It varies from $5.09 \mathrm{~km}^{2}$ (watershed 21) to $130.69 \mathrm{~km}^{2}$ (watershed 13). Watersheds 5,13 and 15 are relatively larger in size $\left(>100 \mathrm{~km}^{2}\right)$, whereas watersheds $2,3,4,6,7,9,10,11,12,16,17,19,20,21$, $22,23,27,28,29,32,34$ and 36 are relatively smaller in size $\left(<25 \mathrm{~km}^{2}\right)$. It is found that the aerial extents of the watersheds of the plateau portion are relatively greater than the watersheds of the slope. The rest of the watersheds have moderate areal extents (ranging from 25 to $100 \mathrm{~km}^{2}$ ).

Morisawa (1962) has observed that the mean annual runoff and catchment area to be directly related to each other. Considering the above views, it can be said that for watershed 5, 13 and 15 (which posses relatively greater areal extent) the mean annual runoff is relatively higher; whereas for watersheds $2,3,4,6,7,9,10,11,12,16,17,19$, $20,21,22,23,27,28,29,32,34$ and 36 , the mean annual runoff is relatively lower.

\section{Form factor $\left(R_{f}\right)$}

Horton (1932) expressed the shape of the watershed as form factor and defined it as a dimensional ratio of the area to the watershed length. It has been calculated by the formulae as,

$F=A / L^{2}$

where $F$-form factor, $A$-watershed area, $L$-watershed length. For circular watershed, the form factor value is found to be 1 and for elongated watershed the value is 0 . The form factor values obtained for the watersheds of the study area are shown in Table 3, and it ranges from 0.11 (watershed 12) to 0.92 (watershed 2). Lower form factor values are found for the watersheds $9,12,17,21,30$ and 34 and owing to their low values these can be inferred as elongated watershed. Higher form factor values $(>0.5)$ are found for watersheds 2, 27, 28 and 35, and it can be inferred that these watersheds have nearly a circular shape. The watersheds with high form 
Table 3 Aerial aspects of the watersheds in Kalrayan hills

\begin{tabular}{|c|c|c|c|c|c|c|c|c|c|c|}
\hline Sub-basin no. & Area (in $\mathrm{Sq} \mathrm{Km}$ ) & $\begin{array}{l}\text { Basin } \\
\text { length (in } \\
\mathrm{Km} \text { ) }\end{array}$ & $\begin{array}{l}\text { Perimeter } \\
\text { (in } \mathrm{Km} \text { ) }\end{array}$ & $D$ & $F_{s}$ & $R_{f}$ & $R_{c}$ & $R_{e}$ & $L_{o}$ & $\mathrm{CCM}$ \\
\hline 1 & 77.02 & 17.75 & 56 & 2.75 & 3.93 & 0.24 & 0.31 & 0.56 & 0.18 & 0.36 \\
\hline 2 & 8.86 & 3.1 & 13.5 & 2.93 & 3.72 & 0.92 & 0.61 & 0.61 & 0.17 & 0.34 \\
\hline 3 & 15.05 & 7 & 21 & 2.99 & 4.25 & 0.31 & 0.43 & 0.62 & 0.17 & 0.33 \\
\hline 4 & 8.75 & 6 & 17 & 2.46 & 3.2 & 0.24 & 0.38 & 0.56 & 0.2 & 0.41 \\
\hline 5 & 107.98 & 19.65 & 64 & 2.32 & 5.05 & 0.28 & 0.33 & 0.6 & 0.21 & 0.43 \\
\hline 6 & 18.19 & 8.25 & 25.5 & 1.9 & 3.85 & 0.27 & 0.35 & 0.58 & 0.26 & 0.53 \\
\hline 7 & 9.51 & 5.7 & 14.5 & 2.68 & 3.05 & 0.29 & 0.57 & 0.61 & 0.19 & 0.37 \\
\hline 8 & 64.09 & 14.1 & 47.5 & 2.44 & 6.26 & 0.32 & 0.44 & 0.64 & 0.2 & 0.41 \\
\hline 9 & 6 & 5.7 & 13 & 1.33 & 0.66 & 0.18 & 0.45 & 0.48 & 0.37 & 0.75 \\
\hline 10 & 7.58 & 5.75 & 13 & 1.91 & 3.45 & 0.23 & 0.56 & 0.54 & 0.26 & 0.52 \\
\hline 11 & 19.48 & 9.4 & 22.5 & 2.75 & 3.85 & 0.22 & 0.48 & 0.53 & 0.18 & 0.36 \\
\hline 12 & 9.36 & 9.2 & 19.5 & 3.79 & 5.34 & 0.11 & 0.31 & 0.37 & 0.13 & 0.26 \\
\hline 13 & 130.69 & 22.75 & 66.5 & 2.93 & 4.04 & 0.25 & 0.37 & 0.57 & 0.17 & 0.34 \\
\hline 14 & 34.94 & 11.5 & 27.5 & 2.13 & 4.75 & 0.26 & 0.58 & 0.58 & 0.23 & 0.47 \\
\hline 15 & 120.09 & 22.85 & 65.5 & 3.65 & 5.8 & 0.23 & 0.35 & 0.54 & 0.14 & 0.27 \\
\hline 16 & 12.22 & 5.6 & 13.5 & 3.27 & 3.85 & 0.39 & 0.84 & 0.7 & 0.15 & 0.3 \\
\hline 17 & 15.12 & 10 & 25 & 2.51 & 1.26 & 0.15 & 0.3 & 0.44 & 0.2 & 0.4 \\
\hline 18 & 28.79 & 10.75 & 27 & 2.9 & 3.13 & 0.25 & 0.5 & 0.56 & 0.17 & 0.34 \\
\hline 19 & 6.97 & 5.5 & 13 & 1.51 & 0.72 & 0.23 & 0.52 & 0.54 & 0.33 & 0.66 \\
\hline 20 & 21.55 & 9.4 & 24.5 & 2.83 & 3.94 & 0.24 & 0.45 & 0.56 & 0.18 & 0.35 \\
\hline 21 & 5.09 & 6.1 & 13.5 & 2.55 & 2.95 & 0.14 & 0.35 & 0.42 & 0.2 & 0.39 \\
\hline 22 & 21.54 & 6.65 & 18.5 & 3.09 & 3.85 & 0.49 & 0.79 & 0.79 & 0.16 & 0.32 \\
\hline 23 & 16.3 & 7.5 & 19 & 1.79 & 1.9 & 0.29 & 0.57 & 0.61 & 0.28 & 0.56 \\
\hline 24 & 29.18 & 8 & 29 & 2.73 & 3.6 & 0.45 & 0.44 & 0.76 & 0.18 & 0.37 \\
\hline 25 & 31.89 & 9.7 & 29.5 & 2.38 & 4.2 & 0.34 & 0.46 & 0.66 & 0.21 & 0.42 \\
\hline 26 & 32.86 & 10 & 30 & 3.64 & 5.54 & 0.33 & 0.46 & 0.65 & 0.14 & 0.27 \\
\hline 27 & 12.98 & 5 & 15.5 & 2.62 & 2.39 & 0.52 & 0.68 & 0.81 & 0.19 & 0.38 \\
\hline 28 & 14.16 & 5.25 & 17.5 & 2.51 & 2.61 & 0.51 & 0.58 & 0.81 & 0.2 & 0.4 \\
\hline 29 & 6.68 & 5.05 & 16 & 3.29 & 3.59 & 0.26 & 0.33 & 0.28 & 0.15 & 0.3 \\
\hline 30 & 29.59 & 11.6 & 30.5 & 2.87 & 3.85 & 0.19 & 0.34 & 0.49 & 0.17 & 0.35 \\
\hline 31 & 49.42 & 10.2 & 37.5 & 2.57 & 3.56 & 0.48 & 0.44 & 0.78 & 0.19 & 0.39 \\
\hline 32 & 11.75 & 5 & 14.5 & 6.04 & 9.62 & 0.47 & 0.7 & 0.77 & 0.08 & 0.16 \\
\hline 33 & 97.55 & 16.25 & 47.5 & 2.79 & 4.12 & 0.37 & 0.32 & 0.68 & 0.18 & 0.36 \\
\hline 34 & 5.91 & 5.5 & 13.5 & 3.21 & 5.08 & 0.19 & 0.41 & 0.5 & 0.15 & 0.31 \\
\hline 35 & 29.09 & 7 & 29 & 3.33 & 4.85 & 0.59 & 0.43 & 0.87 & 0.15 & 0.3 \\
\hline 36 & 9.13 & 5 & 15 & 3.23 & 4.16 & 0.36 & 0.51 & 0.68 & 0.15 & 0.31 \\
\hline
\end{tabular}

factor values have the high peak flows for shorter duration, whereas elongated watershed with low form factor values will have a flatter peak of flow for larger duration (Nautiyal 1994). Flood flows of elongated watersheds are easier to manage than that of circular watersheds. It is observed that the watersheds 2, 27, 28 and 35 have higher peak flows for shorter duration. On the other hand, watersheds 9, 12, 17, 21,30 and 34 have flatter peak flows for longer duration.

\section{Stream frequency $\left(F_{s}\right)$}

Stream frequency is the number of stream segments per unit area (Horton 1945). It is obtained by dividing the total number of streams by the total watershed area. Stream frequency values were found to range from 0.66 (watershed 19) to 9.62 (watershed 32). Stream frequencies which are higher $(>5)$ were noticed for watersheds $5,8,12,15,26$, 32 and 34. On the other hand, for watersheds $9,10,17$ and 23 the stream frequencies were found to be low $(<2.5)$. 


\section{Circulatory ratio $\left(R_{c}\right)$}

Circularity ratio is the ratio of the area of the watershed to the area of a circle having the same circumference as the perimeter of the watershed (Miller 1957; Strahler 1964). It is expressed by the following relationship

$C=4 \pi A / \rho^{2}$

where $C$-circularity ratio, $A$-area of the watershed, $\rho$ watershed perimeter Miller (1957); $A$ value of 0.0 reflects a highly elongated shape and the value of 1.0 a circular shape (Miller 1957; Schumn 1954). The circularity ratio values obtained for the study area are shown in Table 3 . The values vary from 0.3 (watershed 17) to 0.84 (watershed 16). Watersheds which have higher circularity values $(>0.6)$ include watersheds 2, 16, 22, 27 and 32, and these reflect the circular shape of the watershed. Whereas the lower values $(<0.4)$ include the watersheds $1,4,5,13,15,17,21,29$ and 30 and these reflect their elongated shape.

\section{Elongation ratio $\left(R_{e}\right)$}

The elongation ratio is the ratio between the diameter of a circle of the same area as the drainage watershed and the maximum length of the watershed. The elongation ratio values estimated for the various watersheds of the study area are shown in Table 3. The elongation ratio values vary from 0.28 (for watershed 29) to 0.87 (for watershed 35). The watersheds $1,2,3,4,5,6,7,8,10,11,13,14,15,16,17,18$, $19,20,22,23,24,25,26,27,28,31,32,33,35$ and 36 have higher values $(>0.5)$ while the watersheds $9,12,17,21,29$, 30 and 34 have lower values $(<0.5)$. The parameters such as form factor, circularity ratio and elongation ratio are useful to understand the shape of the drainage watershed and it is significant since it affects the stream drainage characteristics (Strahler 1968).

\section{Drainage density $(D)$}

Drainage density is a measure to analyze the length of different streams per unit area, and it is obtained by dividing the total stream length by the total watershed area. The drainage density values estimated for the various watersheds of the study area are given in Table 3. It is observed that the drainage density varies from a minimum of $1.33 \mathrm{~km}^{-1}$ (watershed 9) to a maximum of $6.04 \mathrm{~km}^{-1}$ (watershed 32). In the study area, the drainage density values were found to be low $\left(<1.5 \mathrm{~km}\right.$ per km$\left.{ }^{2}\right)$ for watersheds $6,9,10,19$ and 23. On the other hand, drainage density was found to be high (>3.5 km per $\mathrm{km}^{2}$ ) for watersheds 12, 15, 26 and 32. For rest of the watersheds, the drainage density was found to be moderate. Drainage density has increasingly been appreciated to be a fundamental indicator of a drainage watershed and a valuable index of drainage watershed process like erosion and sediment output (Morisawa and Clayton 1985). Drainage density (Dd) helps to identify the landscape dissection, runoff potential, infiltration capacity of the land, climatic conditions and vegetation cover of the basin (Verstappen 1983; Macke 2001; Reddy et al. 2004). Patton (1988) has observed that the areas of high drainage density are a result of erosion and dissection by overland flow, low drainage density areas are the product of runoff possess dominated by infiltration and sub-surface flow. By considering the above views, it is observed that in the watersheds of the study area where the drainage density values are high $(>3.5 \mathrm{~km} / \mathrm{sq} . \mathrm{km})$ viz. watersheds $12,15,26$ and 32 , overland flow is dominant whereas the watersheds of 6, 9, 10, 19 and 23 (where drainage density is relatively low) infiltration and sub-surface flow are dominant.

\section{Length of overland flow $\left(L_{0}\right)$}

The length of overland flow is a measure of stream spacing or degree of dissection. Horton (1945) used this term to refer to the length of the runoff of the rainwater on the ground surface before it gets localized into definite channels. Since this length of overland flow at an average is about half the distance between the stream channels, Horton for the sake of convenience had taken it to be roughly equal to the reciprocal of drainage density. For the present analysis, half the reciprocal of drainage density for each watersheds of the study area were estimated and are shown in Table 3. In the watersheds of the study area, the length of overland flow values varies from 0.08 (watershed 32) to 0.37 (watershed 9). These estimations mean that the rain water has to run over $0.08 \mathrm{~km}$ and $0.37 \mathrm{~km}$ for watersheds 32 and watershed 9 , respectively, before it gets concentrated in stream channels. Smaller the values of length of overland flow, greater the surface runoff enter the stream. In a relatively uniform terrain, less rainfall is sufficient to contribute a significant volume of surface runoff to stream discharge, when the value of length overland flow is small than when it is large (Rao 1978).

In the watersheds of the study area, which have lower length of overland flow values $(<0.2 \mathrm{~km}), 1,2,3,7,11$, $12,13,15,16,18,20,22,24,26,27,29,30,31,32,33,34$, 35 and 36 , the rainfall gets concentrated quickly in stream channels (requiring to travel just $0.21 \mathrm{~km}$ before getting concentrated in stream channels). Owing to their low values, it is evident that lesser rainfall is sufficient to contribute a significant volume of surface runoff to stream discharge in these watersheds. Whereas the watersheds $6,9,10,19$ and 23 the rainwater travels longer distances $(0.25 \mathrm{~km}$ or more $)$ before getting concentrated into the stream channels. It is further inferred that more rainfall is essential to contribute 
a significant volume of surface runoff to stream discharge in these watersheds than the rest of the watersheds of the study area. It is also important here that the watersheds which are having high Lg may be characterized by mature geomorphic stage (Thomas et al. 2010).

\section{Constant of channel maintenance (CCM)}

Constant of channel maintenance is the area necessary to maintain $1 \mathrm{ft}$ of drainage channel. The constant of channel maintenance represents the drainage area required to maintain one unit of channel length; hence, it is a measure of watershed erodibility. Schumn (1954) proposed the use of the reciprocal of drainage density for calculating the constant of channel maintenance, and the same method has been adopted for the present study. Regions of resistant rock type or with the surface of high permeability or with good forests cover should have a high constant of channel maintenance and a low drainage density. Similarly, regions of weak rock types or region with little or no vegetation and low soil infiltration and permeability should have low constant of channel maintenance and high drainage density. The constant of channel maintenance varies from 0.16 (watershed 32) to 0.75 (watershed 9). Lower values (less than 0.3) are found for watershed 12, 15, 26 and 32 (Table 3). These values reflect the low infiltration and permeability, poor vegetal cover and weak rock types. On the other hand, the constant of channel maintenance values are found to be higher $(>0.5)$ for watersheds $6,9,10$ and 23 which reflect the higher infiltration and permeability of the materials, fairly good vegetal cover and relatively resistant rock type. The rest of the watersheds have moderate infiltration and permeability of the surface material, moderate vegetal cover and moderate resistant rocks.

\section{Relief aspects}

Relief is an important attribute of terrain in general and the drainage watershed in particular. According to Strahler (1968), relief measures are indicative of the potential energy of the drainage system because of its elevation above the mean sea level. The relief aspects considered for the present study include watershed relief, relative relief, relief ratio and ruggedness number (Table 4). The procedures followed to analyze the relief aspects and the results are discussed in the following section.

\section{Basin relief or relative relief $(\mathrm{H})$}

Watershed relief was computed by finding the arithmetic difference between the maximum and the minimum elevations in a given watershed. The lowest relief value was found to be for watershed $9(42 \mathrm{~m})$, and highest relief value was found to be for watershed 35 (1108 m) (Table 4). Among the watersheds of the study area, watersheds 2, 9, 10,19 and 36 are found to possess low relief of $(<400 \mathrm{~m})$ and watersheds $5,13,15,25,26,28,29,30,31$ and 33 possess high relief $(>800 \mathrm{~m})$.

Anhert (1970) and Gregory and Walling (1973) have shown that mean denudation rate is directly proportional to mean watershed relief. Form these observations, it is likely that in watersheds $5,13,15,25,26,28,29,3031$ and 33 , the mean denudation rates are relatively higher. On the other hand, the mean denudation rates are relatively lower for watersheds 2, 9, 10, 19 and 36. The influence of relief is inextricably bound up with other watershed characteristic and is of greater significance to some indices of watershed response particularly peak runoff rates and sediment delivery than others (Gregory and Walling 1973). Watershed relief is an index of the potential energy available in the drainage watershed; the greater the relief, the greater are erosional forces acting on the watershed (Patton1988). In the watershed 5, 13, 15, 25, 26, 28, 29, 30,31 and 33, the erosional forces are relatively higher. Watersheds 2, 9, 10, 19 and 36 the erosional forces are relatively less. But in the rest of the watersheds, the erosional forces are moderate.

\section{Relief ratio $(\mathrm{Rh})$}

When watershed relief is divided by the horizontal distance on which it is measured, it results in a dimensionless relief ratio (Schumn 1954). It measures the overall steepness of a drainage watershed and is an indicator of the intensity of erosion process.

The relative relief values obtained from the above relationship for the watersheds of the study area are given in Table 4 . The maximum relative relief value was found to be for watershed 28 (1.10), and the minimum value was found to be for the watershed $19(0.06)$. The watersheds where relative relief values were found to be low $(<0.5)$ are watersheds $1,2,4,8,10,17,19,24,33,35$ and 36 . Whereas, the watersheds where relative relief values were found to be high $(>1.0)$ are watersheds 28,29 , and 32 . For the other watersheds, the relative relief was found to be moderate (ranging from 0.5 to 1 ). The relief ratio values vary from a minimum of 0.007 (watershed 9) to 0.1943 (watershed 28). Watersheds with low relative relief $(<0.05)$ include watersheds like $1,5,9,10,13,15,17$ and 19 . Whereas watersheds with higher relative relief $(>0.1)$ are watersheds 2, 4, 26, 27, 28, 29, 32 and 34 (Table 4). The possibility of a close correlation between relief ratio and hydrologic characteristic watersheds is the sediment loss per unit is directly related with relief ratio (Schumn 1954). 
Table 4 Relief aspects of the watersheds in Kalrayan hills

\begin{tabular}{|c|c|c|c|c|c|}
\hline Basin no. & $\begin{array}{l}\text { Maximum } \\
\text { height (m) }\end{array}$ & $\begin{array}{l}\text { Minimum } \\
\text { height }(\mathrm{m})\end{array}$ & Basin relief $(\mathrm{m})$ & Relief ratio $(\mathrm{Rh})$ & $\begin{array}{l}\text { Ruggedness } \\
\text { number }(N)\end{array}$ \\
\hline 1 & 912 & 180 & 732 & 0.0412 & 0.3812 \\
\hline 2 & 522 & 195 & 327 & 0.1055 & 0.1815 \\
\hline 3 & 845 & 190 & 655 & 0.0936 & 0.3709 \\
\hline 4 & 847 & 165 & 682 & 0.1137 & 0.3177 \\
\hline 5 & 987 & 170 & 817 & 0.0416 & 0.359 \\
\hline 6 & 850 & 175 & 675 & 0.0818 & 0.2429 \\
\hline 7 & 632 & 167 & 465 & 0.0816 & 0.236 \\
\hline 8 & 904 & 179 & 725 & 0.0514 & 0.335 \\
\hline 9 & 200 & 158 & 42 & 0.0073 & 0.0106 \\
\hline 10 & 263 & 160 & 103 & 0.018 & 0.0372 \\
\hline 11 & 810 & 160 & 650 & 0.0691 & 0.3385 \\
\hline 12 & 680 & 162 & 518 & 0.0563 & 0.3718 \\
\hline 13 & 1072 & 190 & 880 & 0.0387 & 0.4883 \\
\hline 14 & 994 & 195 & 799 & 0.0695 & 0.3223 \\
\hline 15 & 1298 & 190 & 1108 & 0.0485 & 0.7659 \\
\hline 16 & 703 & 162 & 541 & 0.0966 & 0.335 \\
\hline 17 & 240 & 126 & 114 & 0.0114 & 0.0542 \\
\hline 18 & 804 & 126 & 678 & 0.0631 & 0.3724 \\
\hline 19 & 180 & 137 & 43 & 0.0078 & 0.0123 \\
\hline 20 & 804 & 138 & 666 & 0.0708 & 0.357 \\
\hline 21 & 565 & 138 & 427 & 0.07 & 0.2062 \\
\hline 22 & 817 & 160 & 657 & 0.0988 & 0.3845 \\
\hline 23 & 771 & 182 & 589 & 0.0785 & 0.1997 \\
\hline 24 & 771 & 184 & 587 & 0.0734 & 0.3035 \\
\hline 25 & 1132 & 185 & 947 & 0.0976 & 0.4269 \\
\hline 26 & 1298 & 198 & 1100 & 0.11 & 0.7583 \\
\hline 27 & 950 & 206 & 744 & 0.1488 & 0.3692 \\
\hline 28 & 1250 & 230 & 1020 & 0.1943 & 0.4849 \\
\hline 29 & 1150 & 240 & 910 & 0.1802 & 0.567 \\
\hline 30 & 1289 & 238 & 1051 & 0.0906 & 0.5713 \\
\hline 31 & 1247 & 256 & 991 & 0.0971 & 0.4824 \\
\hline 32 & 1059 & 278 & 781 & 0.1562 & 0.8934 \\
\hline 33 & 1218 & 375 & 843 & 0.0519 & 0.4454 \\
\hline 34 & 987 & 360 & 627 & 0.114 & 0.3812 \\
\hline 35 & 1024 & 435 & 589 & 0.0814 & 0.3715 \\
\hline 36 & 900 & 540 & 360 & 0.072 & 0.2202 \\
\hline
\end{tabular}

\section{Ruggedness number (N)}

The ruggedness number has been calculated from the following relationship suggested by (Hart 1986)

$H=\frac{\text { Relief of the watershed }}{D} \times 5280$

The ruggedness number ranges from 0.0106 (watershed 9) to 0.89 (watershed 32). Drainage watersheds with lower $(<0.3)$ ruggedness number values are found in the watersheds $2,6,7,9,10,17,19,21,23$ and 32 (Table 4). It has been established that relative peak discharge increases with increased drainage watershed ruggedness number (Patton 1988). Watershed with higher ruggedness number values (greater than 0.5 ) is found for watersheds 15 , 26, 29, 30 and 32. From the view expressed by (Patton 1988), it is inferred that in the watersheds where the ruggedness number is higher viz. 15, 26, 29, 30 and 32, the peak discharges are likely to be relatively higher. But for the watersheds $2,6,7,9,10,17,19,21,23$ and 36, the peak discharges are likely to be relatively lesser. The analysis of the various drainage morphometric parameters has helped to understand the nature of processes, and the 
surface material in the watersheds of the study area and the findings are summarized below.

\section{Interpretations on the basis of individual morphometric parameter}

\section{Mean annual runoff}

Literatures pertaining to drainage morphometry have revealed that parameters such as total stream length and watershed area are very much useful for understanding the mean annual runoff character in a drainage watershed. The analysis of total stream length data and watershed area data have revealed that for watersheds $2,3,4,5,6,7,9,11,12$, $13,15,17,18,19,20,21,22,23,24,25,27,28,29,30,31$, 32,33 and 36.

\section{Mean denudation rate}

The mean denudation rates of the watersheds were assessed from the watershed relief data. The results of the analysis are described below. Mean denudation rates were found to be moderate in watersheds 5 and 14 . The watersheds 25 , $26,28,29,30$ and 31 found to have relatively low mean denudation rates.

\section{Dominant watershed process}

Drainage density, a useful index in understanding whether overland flow or sub-surface flow, is dominant in an area. In watersheds $12,15,16,22,26,29,32,35$ and 36 overland flow is found to be more dominant. In watersheds 5, 6, 8, 9, $13,14,19$ and 23 sub-surface flow and infiltration are found to be more dominant.

\section{Geological processes}

Bifurcation ratio serves as useful index in understanding geological disturbances in an area. In the present study, the bifurcation ratio values obtained for the various watersheds of the study area have been used to bring out the watersheds which are structurally disturbed. Among the watersheds, watersheds 34 and 36 found to have undergone greater structural disturbances and their drainage patterns have been relatively highly distorted by the structural disturbances.

\section{Sediment yield per unit area}

The sediment yield/unit area is found to be relatively higher in watersheds 9,10,17,19 and 34. The sediment yield/unit area is found to relatively lower in watershed $4,5,13,15$, 26,27,28,29 and 32 .

\section{Peak discharge rates}

Ruggedness number values are made for understanding the peak discharge character of the watershed of the study area. It is noted to be higher in watershed 26, 29, 30 and 32 and watersheds $2,6,9,10,15,17,19,21,22$ and 36 have lower peak discharge rates, whereas in watersheds $1,3,4,11,12$, $18,20,22,24$ and 27 have moderate peak discharge rates.

\section{Multi-criteria analysis}

Numerical analysis of hydro-geo-chemical data has been attempted to determine the (Lawrence and Upchurch 1982). Correlation and factor analysis are widely used in statistical or numerical concepts for parametric classification of modeling studies (Balasubramanian et al. 1985). Statistical data generally provide a better representation than graphical data because (1) there are a finite number of variables that can be considered, (2) variables are generally limited by convention to major ions, and (3) superior relationships may be deduced by use of certain procedures.

\section{Factor analysis}

Factor analysis aims to explain observed relation between numerous variables in terms of simpler relations (Cattel 1965). In factor analysis, the basic concept is expressed in the following formula:

$Z_{j}=a_{j 1} f_{1}+a_{j 1} f_{2} \cdots+a_{j 1} f_{m}+e_{j j} \quad j=1,2, \ldots p$

where $z$ is the measured value, $f$ the factor score, a the factor loading, e the residual term accounting for errors or other sources of variation, $I$ the sample number, $j$ the variable number and $\mathrm{m}$ is the total number of factors (Anazawa and Ohmori 2001).

Factor analyses allow the determination of basic independent dimensions of variables. The SPSS software used for the calculation provides a numerical value resulting from different variants as components and initial eigen values for each species. With the help of linear combinations, a large number of variables can be reduced to a few factors and these factors can be interpreted in terms of new variables. There exist numerous solution methods and variations for determination of factors (Mahlknecht et al. 2004). Principal component analyses (PCA), which aim to load most of the total variance into one factor, are used in the present case, and factors were extracted through the principal extraction method (Mahlknecht et al. 2004). The varimax rotation-one factor, which explains mostly one variable, was selected. In order to limit the number of factors to be extracted, only factors with eigen values higher than one were taken into consideration (Kaiser 1958). Creating a distribution map 
of the factor scores in this way tests the usefulness of the results, and the factor scores are a measure of the statistical weight of each case on the extracted factors. The factor analysis model is assumed to represent an overall variance of the data set and structure expressed in the pattern of variance and covariance between the variables and the similarities between the observations (Davis 1986). Contribution of a factor is said to be significant when the corresponding eigen value is greater than unity (Briz-Kishore and Murali 1992). In general, the factor will be related to the largest eigen value and will explain the greatest amount of variance in the data set.

A total of four factors were identified from the morphometric parameters of the three aspects of watersheds as shown in Table 5. It was observed in terms of total variance, loading matrix and eigen value exhibited by the same factor. Factor I of the principal component factor matrix of the aspects was characterized by the strong loadings of drainage density $(D)$, stream frequency $\left(F_{s}\right)$ and ruggedness number (R No.) of $0.914,0.851$ and 0.853 , respectively, and accounts for $37.81 \%$ of the variance with an eigen value of 4.537 .

From the percentage variance of $37.81 \%$, it is well established that $D, F_{s}$ and $\mathrm{R}$ No are in a series and directly related to one another. It is interesting to mention that two ( $D$ and $F_{s}$ ) of the three coordinated factors belong to aerial aspect and the remaining one ( $\mathrm{R} \mathrm{No}$ ) pertains to the relief aspect. These three factors contribute toward the incredible process of sub-surface flow of water leading to the ultimate formation of watershed with high potential of groundwater.

Factor II for the three aspects registered the loadings of form factor $R_{f}(0.797)$, circulatory ratio, $R_{c}(0.778)$ and elongation ratio, $R_{e}(0.728)$ with the variance of $24.23 \%$ and eigen value of 2.908 . These three factors are pertinent to the aerial aspect of drainage morphometry and are inter-dependent to one another. As these are accumulated in the form of a single component, it can be inferred that the possible sub-surface flow occurs due to the long travel time of water along the watersheds of circular and elongated shape. Hence,
Table 5 Factor analysis for the linear, aerial and relief aspects of drainage morphometric parameters

\begin{tabular}{|c|c|c|c|c|c|}
\hline Principal components & PC-1 & PC-2 & PC-3 & PC-4 & Communality \\
\hline \multicolumn{6}{|c|}{ Principal component loadings } \\
\hline$D$ & 0.914 & 0.062 & -0.006 & -0.341 & 0.944 \\
\hline$N$ & 0.853 & -0.060 & -0.225 & 0.048 & 0.891 \\
\hline$F_{s}$ & 0.851 & -0.015 & -0.159 & -0.053 & 0.742 \\
\hline $\mathrm{ABR}$ & 0.413 & -0.655 & 0.334 & 0.145 & 0.736 \\
\hline$R_{e}$ & 0.280 & 0.723 & -0.058 & 0.422 & 0.709 \\
\hline$A$ & 0.263 & -0.276 & -0.667 & 0.576 & 0.935 \\
\hline$R_{f}$ & 0.258 & 0.797 & -0.071 & 0.122 & 0.724 \\
\hline $\mathrm{RR}$ & 0.219 & 0.136 & 0.627 & 0.539 & 0.813 \\
\hline PFOS & 0.187 & -0.784 & 0.318 & 0.211 & 0.773 \\
\hline$R_{c}$ & 0.079 & 0.778 & 0.364 & -0.043 & 0.688 \\
\hline $\mathrm{CCM}$ & -0.940 & 0.001 & -0.095 & 0.111 & 0.943 \\
\hline$L_{o}$ & -0.944 & 0.003 & -0.095 & 0.102 & 0.950 \\
\hline Eigen value & 4.54 & 2.91 & 1.29 & 1.03 & \\
\hline Per. Var & 37.81 & 24.23 & 10.72 & 8.56 & \\
\hline Cum. Per. Var & 37.81 & 62.04 & 72.76 & 81.31 & \\
\hline \multicolumn{6}{|c|}{ Rotated component matrix } \\
\hline$D$ & 0.967 & 0.056 & -0.116 & -0.063 & \\
\hline R No. & 0.826 & 0.019 & 0.317 & 0.036 & \\
\hline$F_{s}$ & 0.844 & 0.039 & 0.193 & 0.014 & \\
\hline $\mathrm{ABR}$ & 0.366 & -0.680 & 0.067 & 0.364 & \\
\hline$R_{e}$ & 0.166 & 0.766 & 0.204 & 0.357 & \\
\hline$A$ & 0.147 & -0.065 & 0.946 & -0.031 & \\
\hline$R_{f}$ & 0.214 & 0.810 & -0.008 & 0.140 & \\
\hline $\mathrm{RR}$ & 0.066 & 0.062 & -0.070 & 0.858 & \\
\hline PFOS & 0.133 & -0.802 & 0.120 & 0.347 & \\
\hline$R_{c}$ & 0.064 & 0.680 & -0.441 & 0.291 & \\
\hline $\mathrm{CCM}$ & -0.936 & 0.001 & 0.013 & -0.167 & \\
\hline$L_{o}$ & -0.938 & 0.004 & 0.006 & -0.174 & \\
\hline
\end{tabular}


these ratios decide the potential occurrence of groundwater in the watersheds of the study area.

Factor III of the aspects was with the loadings of Relief Ratio, RR (0.627) with a percentage variance of $10.72 \%$ and eigen value of 1.286. This accounts for the watersheds with steep slope facilitating more erosion and leads to the greater discharge of sediments. However, this nature lessens the groundwater potential in the watersheds. In supporting the factor III, it is meticulously illustrated through the box patterns which demonstrate the overland flow of the watersheds.

The loading of area $(A)$ alone was registered under factor IV with a percentage variance and eigen value of $8.56 \%$ and 1.027 , respectively. Mean annual runoff, as governed by the area of the watershed, is associated with both the sub-surface and surface flow of groundwater of present focus. It is again established that the studied area experiences the occurrence of both flow (surface and sub-surface) types and hence the groundwater potential zones.

\section{Box and whisker plots}

The box and whisker plot (Tukey 1977) is a quick way of examining one or more sets of data graphically. The box plots may seem more primitive than a histogram or kernel density estimate, but they do have some advantages. They take up less space and are therefore particularly useful for comparing distributions between several groups or sets of data. Box plots have evolved into a familiar and useful standard in data interpretation. The plots summarize the information about the shape, dispersion and center of the water quality parametric data of the water samples. They also identify the outliers (an extreme value falling outside the box by more than 1.5 times the inter quartile range).

The degree of association or the strength of a linear relationship between two variables has been evaluated by calculating the coefficient of correlation $(r)$.

The box and whisker plots for drainage density $(D)$ and average bifurcation ratio (ABR) are shown in Fig. 3. The plots explicably show the skewed type in which the median line is not equidistant from the hinges. The skewness patterns of drainage density $(D)$ and average bifurcation ratio (ABR) are skewed left. The upper whisker and the outlier (watershed 34) reflect the occurrence of high distortion of geological structure leading to a poor establishment of the drainage. The other watersheds are confined within the lower whisker and the quartiles of the box plot of ABR.

In addition, a valid inference based on the infiltration ability and overland flow of spotted watersheds can be drawn from the box pattern of drainage $(D)$. The watersheds 9 and 19 , respectively, depicted as outlier and lower whisker seem to associate a remarkable infiltration capability and hence the infiltration is dominant. Conversely, the outlier representing the watershed (No. 32) corroborates the domination of over land flow as a consequence of steep (slope) terrain which further facilitates the erosion and dissection. The other watersheds are well confined in the box pattern and make us understand the participation of both infiltration and overland flow. The gradation in height of the quartile depicts well about the ability of a watershed to avoid infiltration rather than over land flow. The patterns of the boxes of $\mathrm{ABR}$ and D illustrate the groundwater potential especially in watersheds (No. 9 and 19) are quite remarkable based on the recorded values.

The box patterns for form factor $\left(R_{f}\right)$, elongation ratio $\left(R_{e}\right)$ and circulatory ratio $\left(R_{c}\right)$ are skewed left as the median lines are not equidistant with respect to the upper and lower quartiles. As depicted in Fig. 3, an outlier (watershed 2) shows the maximum value of $R_{f}$ and reflects the nature of discharging the entire amount of water within a short span of time. Also, the watersheds (Nos. 27, 28 and 35) fall in the fourth quartile resemble high peak flow in a short time. Conversely, the remaining watersheds of about $89 \%$ seem to possess an appreciable infiltration due to the longer (flatter) travel period of water. On accounting the box pattern of Re, most of the watersheds fall in the second, third and fourth quartiles and suggest the high peak
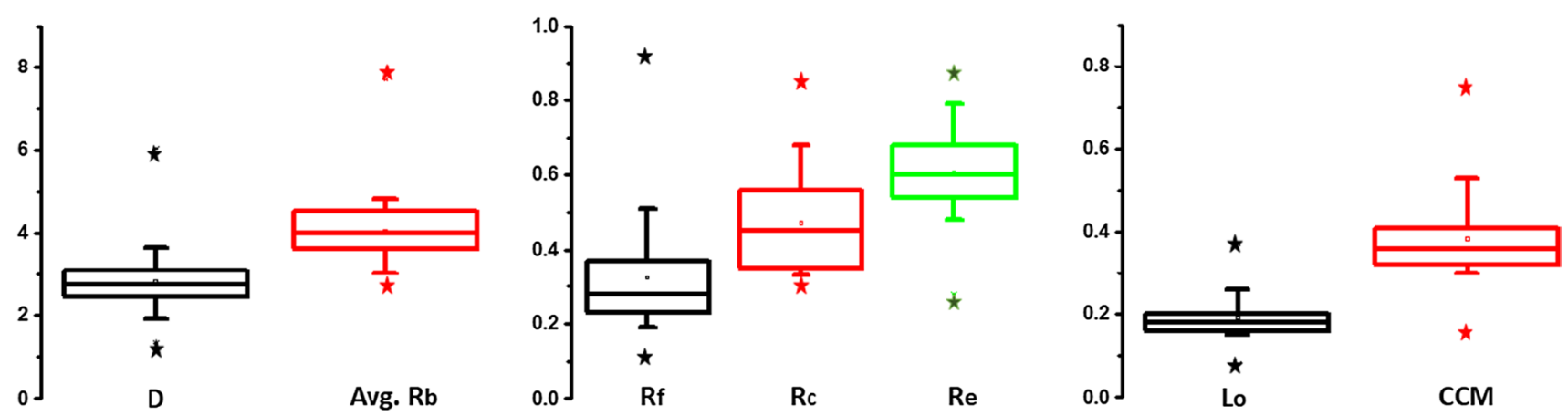

Fig. 3 Box whisker plots for drainage density $(D)$, average bifurcation ratio $\left(R_{b}\right)$, form factor $\left(R_{f}\right)$, circulatory ratio $\left(R_{c}\right)$, elongation ratio $\left(R_{e}\right)$, length of overland flow $\left(L_{o}\right)$ and constant channel maintenance $(\mathrm{CCM})$ 
flow accompanying the elongated travel of water. However, an appreciable infiltration is best executed for these watersheds with respect to the elongated nature and travelled area. In the box plot of $R_{c}$, the convergence of most of the watersheds in the first three quartiles is observed which reveal that the nature of infiltration is dominant unlike the watersheds belong to the fourth quartile.

The box patterns of $L_{o}$ and CCM are observed to be symmetric and skewed-left, respectively. Based on the length of upper whiskers of the box patterns, a spread data describing the length of overland flow and constant channel maintenance could be studied. The watersheds represented as outliers and within the limit of third and fourth quartiles behave to acknowledge the nature of infiltration rather than usual terrain flow. Conspicuously, watershed (No. 32) witnesses the nature of dominating surface flow rather than the sub-surface flow of water. It is apparently illustrated from the box patterns of Fig. 3 that the factors $L_{\mathrm{o}}$ and CCM are directly related to each other.

\section{Hierarchial cluster analysis by dendrogram plots}

In this study, hierarchical cluster analysis was used to group watersheds into separate clusters based on the bifurcation ratio. Although there are a number of hierarchical clustering techniques, all of which are not regularly applied the most widely used measure of ordering is Ward's criterion, which uses an analysis of variance approach that minimizes the sum of squares within the clusters and maximizes the variance between separate clusters (Ward 1963). The results are represented through a dendrogram (or tree plot) and are separated into different clusters. The sample locations are grouped on the vertical axis, and the linkage distances, representing the relative differences between clusters, are shown on the horizontal axis.

The dendrogram (Fig. 4) together drawn for drainage density and average bifurcation ratio illustrates the separation of possible clusters split from eight nodes based on the vertical axis distance. Out of the formed eight nodes, five (n1-n5)

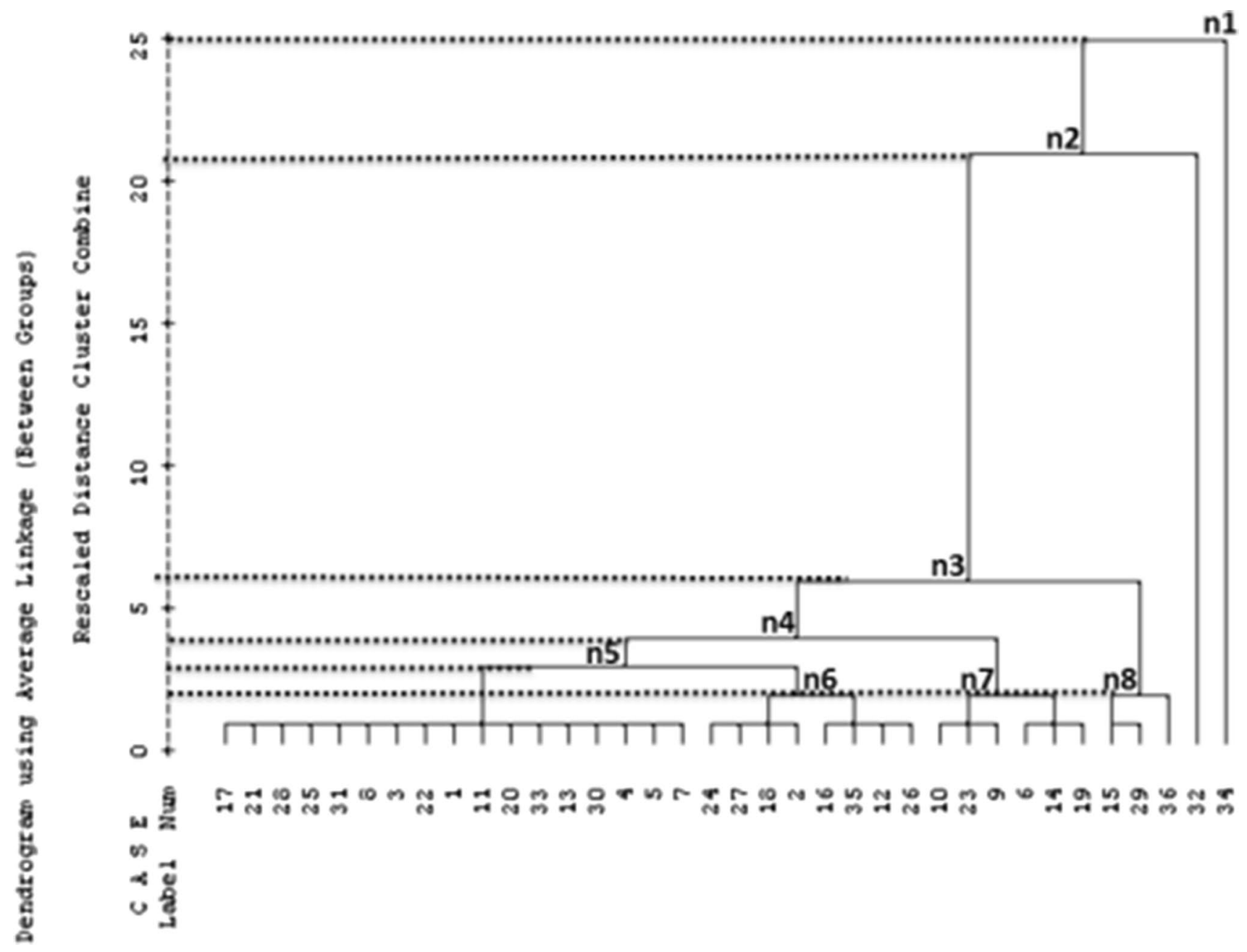

Fig. 4 Dendrogram of the clustered watersheds in the study area 
have distinct variation in their distances where as three (n6-n8) are evaluated to be with the same distance along the vertical axis. The clusters on the right and left hand sides are found to be equal in size for two nodes with vertical distance of 2 . The clustered spots derived from the nodes $\mathrm{n} 6$ and $\mathrm{n} 7$ are very close to each other and each, respectively, split into four and three (as leaf nodes) as right and left branches. Node 6 has eight clustered watersheds with uniformity in behavior with appreciable sub-surface flow of water than the six clustered watersheds constituting node 7. Nevertheless, the watersheds in nodes 6 and 7 exhibit similarity in their surface and sub-surface flow patterns but with less significant difference as approved by the vertical distance scale ( 2 units). There were only few conspicuous clustered watersheds are observed in nodes 1 and 8 . In node 8 , one branched cluster is with a pair of watersheds ( 15 and 29 ) and the other is with only one unpaired watershed (No. 36). Although, these two branches seem to be identical with respect to each other, the domination of infiltration is quite apparent in watershed 36 than in watersheds 15 and 29. The most identified, separated and unique clustered spot is explicably shown at the top with greater vertical distance of 25 units is watershed No. 34. As a matter of fact, this watershed is found with high level of drainage dissection and geological distortion which leads to the enrichment of groundwater locale.

\section{Conclusion}

The study focuses the importance of quantitative morphometric analysis and its consequences in preparing suitable water resource management plan in the hill environment. From the study, it is evident that the drainages are surface expressions/signatures of sub-surface earth system dynamics. The watersheds have bifurcation ratios $2-5$ range which suggests that the drainage networks of the watersheds are well developed. Except watershed 2 and 23 the impact of structural disturbances are relatively less, the structural and the resultant distortion of the drainage pattern is found to be moderate. The denudational rate of watersheds like 3, 4, 6, $11,12,15,18,20,22,23,24,27,32$ and 33 is found to have relatively high. Sediment yield per unit area is relatively more in the eastern and southern slopes. The above findings reveal that the watersheds of the southern slope have higher peak discharge rates whereas in the watersheds of northern slope it is found to be lower. In the western and eastern slopes, the peak discharges are found to be moderate. In the watershed dominant process in eastern slopes, sub-surface flow and infiltration is predominant while in the southern slope especially in the southwestern and southeastern parts overland flow is dominant. In the western and most part of the southern slopes, both the processes are equal in importance. The results of the study can be used as an important tool to prioritize the watersheds according to their hydrological characters. Thus, the results obtained can serve as an essential input for a comprehensive water resources management plan in the study area. In support to the observations, the multi-criteria analytical tools such as factor and hierarchial cluster analyses corroborated the variation of surface flow to sub-surface flow based on the derived principal components and grouped clusters, respectively. The illustration of box patterns made a significant impact from the types of quartiles, whiskers and outliers which denote the watersheds of present study area.

Acknowledgements The authors are thankful to the University Grants Commission (UGC) for providing financial support to assess the watershed characters of the Kalrayan hills through a major project on "Watershed characterization and prioritization for sustainable natural resources management: A case study from Kalrayan hills, part of Eastern Ghats using remote sensing and GIS" (F. No. 34-52।2008 (SR) dated 30.12.2008). It is imperative to render our thankfulness to the administrative authorities of the Bharathidasan University for providing necessary infrastructure facilities to carry out this project.

Open Access This article is distributed under the terms of the Creative Commons Attribution 4.0 International License (http://creativeco mmons.org/licenses/by/4.0/), which permits unrestricted use, distribution, and reproduction in any medium, provided you give appropriate credit to the original author(s) and the source, provide a link to the Creative Commons license, and indicate if changes were made.

\section{References}

Abrahams AD (1984) Channel networks: a geomorphological perspective. Water Resour Res 20(2):161-188

Ajibade LT, Ifabiyi IP, Iroye KA, Ogunteru S (2010) Morphometric analysis of Ogunpa and Ogbere drainage basins, Ibadan, Nigeria. Ethi J Environ Stud Manage 3(1):13-19

Akar I (2009) How geographical information systems and remote sensing are used to determine morphometrical features of the drainage network of Kastro (Kasatura) Bay hydrological basin. Int J Remote Sens 30(7):1737-1748

Anazawa K, Ohmori H (2001) Chemistry of surface water at a volcanic summit area, Norikura, Central Japan: multivariate statistical approach. Chemosphere 45:807-816. https://doi.org/10.1016/ S0045-6535(01)00104-7

Anhurt F (1970) Functional relationship between denudation, relief and uplift in large, mid-latitude drainage basin. Am J Sci 268:243-263

Balasubramanian A, Sharma KK, Sastri JCV (1985) Geoelectrical and hydrogeochemical evaluation of coastal aquifer of Tambraani basin, Tamil Nadu. Geophysical res Bull 23:203-209

Bardossy A, Schmidt F (2002) GIS approach to scale issues of perimeter-based shape indices for drainage basins. Hydrol Sci 47(6):931-942

Baumgardner RW (1967) Morphometric studies of subhumid and semiarid drainage basin, Texas Panhandle and Northeastern New Mexico, vol 163. Bureau of Economic Geology, University of Texas at Austin, Austin, p 67 
Biswas S, Sudhakar S, Desai VR (1999) Prioritisation of subwatersheds based on morphometric analysis of drainage basin: a remote sensing and GIS Approach. J Ind Soc Remote Sens 27:155-166

Briz-Kishore BH, Murali G (1992) Factor analysis for revealing hydrogeochemical characteristics of watersheds. Environ Geol Water Sci 9:3-9

Cattel RB (1965) Factor analysis: introduction to essentials. Biometrics 21:190-215. https://doi.org/10.2307/2528364

Chaudhary RS, Sharma PD (1998) Erosion hazard assessment and treatment prioritization of Giri River catchment, North Western Himalayas. Indian J of Soil Conserv 26(1):6-11

Chopra R, Dhiman R, Sharrna PK (2005) Morphometric analysis of sub-watersheds in Gurdaspur District, Punjab using remote sensing and GIS techniques. J lnd Soc Remote Sens 33(4):531-539

Clarke JI (1966) Morphometry from maps. In: Dury GH (ed) Essays in geomorphology. American Elsevier publishing Co., New York, pp 235-274

Das S, Pardeshi SD (2018) Morphometric analysis of Vaitarna and Ulhas river basins, Maharashtra, India: using geospatial techniques, Maharashtra, India using geospatial techniques. Appl Water Sci 8:158. https://doi.org/10.1007/s13201-018-0801-z

Davis JC (1986) Statistics and data analysis in Geology. Wiley, New York

Esper AMY (2008) Morphometric analysis of Colanguil river basin and flash flood hazard, San Juan, Argentina. Environ Geol 55:107-111

Gardiner V (1990) Drainage basin morphometry. In: Goudie AS (ed) Geomorphological techniques. Unwin Hyman, London, pp 71-81

Gregory KJ, Walling DE (1973) Drainage basin form and process a geomorphological approach. Edward Arnold, London, p 456

Grohmann HC (2004) Morphometric analysis in Geographic Information Systems: applications of free software GRASS and R. Comput Geosci 30:1055-1067

Hart MG (1986) Geomorphology-Pure and applied. Allen and Unwin Pub. Ltd., London, p 211

Hlaing KT, Haruyama S, Aye MM (2008) Using GIS-based distributed soil loss modeling and morphometric analysis to prioritize watershed for soil conservation in Bago river basin of Lower Myanma. Front Earth Sci China 2(4):465-478

Horton RE (1932) Drainage basin characteristics. Trans Am Geophys Union 13:350-361

Horton RE (1945) Erosional development of streams and their drainage basins: hydrophysical approach to quantitative morphology. Geol Soc Am Bull 56:275-370

Jawaharraj N, Kumaraswamy K, Ponnaiyan K (1998) Morphometric Analysis of the Upper Noyil Basin, Tamil Nadu. Deccan Geograph 36(2):15-30

Kaiser HF (1958) The varimax criterion for analytic rotation in factor analysis. Psychometrica 23(3):187-200

Kouli M, Vallianatos F, Soupios P, Alexakis D (2007) GIS based morphometric analysis of two major watersheds, Western Crete, Greece. J Environ Hydrol 15(1):1-17

Kumar R, Kumar S, Lohni AK, Neema RK, Singh AD (2000) Evaluation of geomorphological characteristics of a catchment using GIS. GIS India 90:13-17

Kumar A, Samuel SK, Vyas V (2014) Morphometric analysis of six sub-watersheds in the central zone of Narmada River. Arab J Geosci 8(8):5685-5712. https://doi.org/10.1007/s12517-014-1655-9

Kumar N, Singh SK, Pandey HK (2018) Drainage morphometric analysis using open access earth observation datasets in a droughtaffected part of Bundelkhand, India. Appl Geomat 10(3):173-189

Kumaraswamy K, Sivagnanam N (1988) Morphometric characteristics of Vaippar basin, Tamil Nadu: a quantitative approach. Indian J Landsc Syst Ecol Stud 11(1):94-101

Lawrence FW, Upchurch SB (1982) Identification of recharge areas using geochemical factor analysis. Groundwater 20(6):680-687
Macke Z (2001) Determination of texture of topography from large scale contour maps. Geogr Bull 73(2):53-62

Mahlknecht J, Steinich B, de Navarro LL (2004) Groundwater chemistry and mass transfers in the Independence aquifer, Central Mexico by using multivariate statistics and mass balance models. Environ Geol 45:781-795

Mahmoud SH, Alazba AA (2015) Hydrological response to land cover changes and human activities in arid regions using a geographic information system and remote sensing. PLoS ONE 10(4):e0125805. https://doi.org/10.1371/journal.pone,0125805

Malik MS, Shukla JP (2018) A GIS-based morphometric analysis of Kandaihimmat watershed, Hoshangabad district, M.P. India. Indian J Geo-mar Sci 47(10):1980-1985

Marchi L, Fontana GD (2005) GIS morphometric indicators for the analysis of sediment dynamics in mountain basins. Environ Geol 48:218-228

Miller VC (1957) A quantitative geomorphic study of drainage basin characteristics in the Clinch Mountain area, Virginia and Tennessee. J Geol 65(1):389-402

Morisawa ME (1962) Quantitative geomorphology of some watersheds in the Appalachian Plateau. Geol Soc Am Bull 73:1025-1046

Morisawa M, Clayton KM (1985) Rivers: forms, processes. Longman, New York, p 222

Moussa R (2003) On morphometric properties of basins, scale effects and hydrological response. Hydrol Process 17(1):33-58

Nag SK, Chakraborty S (2003) Influence of rock types and structures in the development of drainage network in hard rock area. J Indian Soc Remote Sens 31(1):25-35

Nautiyal MD (1994) Morphometric analysis of a drainage basin using aerial photographs: a case study of Khairkuli basin, District Dehradun, Uttar Pradesh. J Indian Soc Remote Sens 22(4):251-261

Nookaratnam K, Srivastava YK, Venkateswarao V, Amminedu E, Murthy KSR (2005) Check dam positioning by prioritization of microwatersheds using SYI model and Morphometric analysisremote sensing and GIS perspective. J Indian Soc Remote Sens 33(1):25-38

Patton PC (1988) Drainage basin morphometry and floods. In: Baker VR, Kochel RC, Patton PC (eds) Flood geomorphology. Wiley, New York, pp 51-65

Patton PC, Baker VR (1976) Morphometry and floods in small drainage basins subject to diverse hydrogeomorphic controls. Water Resour Res 12(5):941-952

Pike RJ (2000) Geomorphometry-diversity in quantitative surface analysis. Prog Phys Geogr 24(1):1-20

Pirasteh S, Pradhan B, Rizvi Syed M (2011) Tectonic process analysis in Zagros Mountain with the aid of drainage networks and topography maps dated 1950-2001 in GIS. Arab J Geosci 4(1-2):171180. https://doi.org/10.1007/s12517-009-0100-y

Radwan F, Alazba AA, Mossad A (2017) Watershed morphometric analysis of Wadi Baish Dam catchment area using integrated GISbased approach. Arab J Geosci 10:2567. https://doi.org/10.1007/ s12517-017-3046-s

Rao G P (1978) Some morphometric techniques with relation to discharge of Musi River Basin, Andhra Pradesh. In: Proceedings symposium on morphology and evolution of landforms, Department of Geology, University of Delhi, pp 168-176

Reddy OGP, Maji AK, Gajibhiye SK (2004) Drainage morphometry and its influence on Land forms characteristics in a basaltic terrain, Central India- a remote sensing and GIS approach. Int J Appl Earth Obs Geoinf 6(1):1-16

Rodriguez-Iturbe I, Valdés JB (1979) The geomorphologic structure of the hydrologic response. Water Resour Res 15(6):1409-1420

Sakthivel R, Manivel M, Alagappa Moses A, Chandramohan A, Anand Vijay D (2003) Hydrogeomorphological Mapping in Kalrayan Hills, Tamil Nadu. Indian J Geomorphol 8(1\&2):1-6

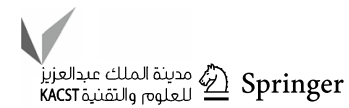


Sakthivel R, Manivel M, Jawahar N, Pugalanthi V, Kumaran Raju D (2007) Role of remote sensing in geomorphic mapping: a case study from Kalrayan Hills, Tamil Nadu. Indian J Geomorphol 11 \& 12(1\&2): 101-110

Sakthivel R, Manivel M, Jawahar Raj N, Pugalanthi V, Ravichandran N, Anand Vijay D (2010) Remote sensing and GIS based forest cover change detection study in Kalrayan hills, Tamil Nadu. J Environ Biol 31:737-747

Sakthivel R, Jawahar Raj N, Pugazhendi V, Rajendran S, Alagappa Moses A (2011) Remote sensing and GIS for soil erosion prone areas assessment: a case study from Kalrayan hills, part of Eastern Ghats, Tamil Nadu, India. Arch Appl Sci Res 3(6):369-376

Saud MA (2009) Morphometric analysis of Wadi Aurnah drainage system, western Arabian peninsula. Open Hydrol J 3:1-10

Schumn SA (1954) The relation of drainage basin relief to sediment loss. Int Assoc Hydrol 36(1):216-219

Shrimali SS, Aggarwal SP, Samra JS (2001) Prioritizing erosion-prone areas in hills using remote sensing and GIS - a case study of the Sukhna Lake catchment, Northern India. Int J Appl Earth Obs Geoinf 3(1):54-60

Singh S (1978) A quantitative analysis of drainage texture of small drainage basins of the Ranchi Plateau. In: Proceeding symposium on morphology and evolution of landforms, Department of Geology, University of Delhi, New Delhi, pp 99-199

Singh S (1998) Drainage systems and patterns, physical geography. Prayag Pustak Bhawan, Allahabad, pp 225-244

Sreedevi PD, Subrahmanyam K, Ahmed S (2005) The significance of morphometric analysis for obtaining groundwater potential zones in a structurally controlled terrain. Environ Geol 47(3):412-420
Sreedevi PD, Owais S, Khan HH, Ahmed S (2009) Morphometric analysis of a watershed of South India Using SRTM data and GIS. J Geol Soc India 73:543-552

Srinivasa VS, Govindaiah S, Gowda HH (2004) Morphometric analysis of sub- watersheds in the Pavagada area of Tumkur district, south India Using remote sensing and GIS techniques. J Indian Soc Remote Sens 32(4):351-362

Strahler AN (1957) Quantitative analysis of watershed geomorphology. Amer Geo Phy Union Trans 38(6):913-920

Strahler AN (1964) Quantitative geomorphology of drainage basin and channel networks. In: Chow VT (ed) Handbook of applied hydrology. McGraw Hill Book, New York, pp 4-76

Strahler AN (1968) Quantitative geomorphology. In: Fairbridge RW (ed) The encyclopedia of geomrophology. Reinhold Book Corporation, New York

Thomas J, Sabu J, Thrivikramaji KP (2010) Morphometric aspects of a small tropical mountain river system, the Southern Western Ghats, India. Int J Digit Earth 3(2):135-156

Tukey JW (1977) Exploratory data analysis. Addison-Wesley, Reading Verstappen HT (1983) Applied geomorphology-geomorphological surveys for environmental development. Elsevier, New York

Ward JH Jr (1963) Hierarchical grouping to optimize an objective function. J Am Stat Assoc 58(301):236-244

Publisher's Note Springer Nature remains neutral with regard to jurisdictional claims in published maps and institutional affiliations. 